the growth of the late 1980s to be ignored. In Tanzania, the policy regime said to be responsible for slow growth was a response to external shocks. In Zambia, much is to be explained by real copper prices, and little by policy.

In sum, Jerven shows African GDP data is unreliable, and argues the importance of policy has been overstated. I would have preferred to see the latter claim substantiated with re-analysis of the data.

JAMES FENSKE, University of Oxford

\title{
SOUTH AMERICA
}

Inglorious Revolution: Political Institutions, Sovereign Debt, and Financial Underdevelopment in Imperial Brazil. By William R. Summerhill. Yale University Press, 2015. Pp. xiii, 342. $\$ 85.00$, cloth.

doi: $10.1017 / \mathrm{S} 0022050716000887$

Inglorious Revolution contributes importantly to economic history from several perspectives. It is a very well-researched, readable, and comprehensive financial history of Brazil during the nineteenth century, and an interesting case study in the linkages between public and private sector finance. The book argues two related hypotheses: (1) the Brazilian state was a successful sovereign borrower in foreign (London) and domestic markets through the nineteenth century; and (2) success with sovereign debt did not translate into success in private sector financial markets. William Summerhill contextualizes this argument within the influential work of Douglass North and Barry Weingast ("Constitutions and Commitment: The Evolution of Institutions Governing Public Choice in Seventeenth-Century England." this Journal 49 [1989]: 803-32), which postulates that institutions protecting sovereign debt obligations are also central to the development of private financial markets. Inglorious Revolution finds that success for a sovereign borrower, defined as the Brazilian state not having completely defaulted on its debt throughout the Imperial regime (1824-1889), is not a sufficient condition for private-sector success. The comparative perspectives of the book are with "successful" (mostly Anglo-American) financial systems and with the abject failures of sovereign debt among the newly independent Spanish American colonies.

Strong governance institutions, embedded in the Constitution, established the foundations necessary for success as a sovereign borrower. These institutions denied the executive branch the unilateral ability to default on either domestic or foreign debt. Summerhill argues that legislators were also purchasers of domestic bonds, and therefore, protected their investment in Imperial debt with constitutional constraints. When turning attention to structuring the institutions of private financial markets, policymaking legislators did not enable company formation and capital accumulation. These arguments unfold in successive chapters that explain his theoretical models, and explore each of the major financial markets germane to the story: foreign and then domestic sovereign debt markets, corporate capital accumulation and banking. The concluding chapter proposes that the end of Imperial governance and financial reform (resulting in sovereign and private market crises) occurred together. Appendices explicate the 
theoretical structure of the hypotheses, the piecing together of very difficult time-series data, and the methodology of determining borrowing costs. Inglorious Revolution analyzes each form of financing with an impressive array of data that includes debt and loan volumes, bond yields, interest rates, rate of corporate formation, close readings of laws and debates. As a result, a fuller understanding of nineteenth-century Brazilian finance emerges than has been previously available. For economic historians of Brazil, this is an important accomplishment. For scholars interested in the interaction between political institutions and economy, this history offers insight on the contingency of institutional development.

As with every work of financial historiography and theory, scholars will debate many of the theoretical and methodological specifications of the study. These debates will include the strength of and methodology for determining the structural breaks in assessing domestic and foreign debt analysis. Do completely different timing of and explanations for breaks in the different markets really make sense, if domestic buyers of sovereign debt successfully united their interests with those of foreign purchasers? Applying structural break analysis to corporate charter issuance over the course of 90 years, with $n=93$ and five breaks, will also raise methodological questions. Further, why does the anecdotal history of cronyism in commercial banking (in Rio de Janeiro only) not extend to the other financial markets under examination?

This review raises three interpretive questions that merit future research. First, Inglorious Revolution heavily focuses on the years 1853-1889, a period when the state could freely borrow in domestic and international markets and when efforts to reform private finance encountered serious constraints. In the earlier period of the Empire (18241853) the state neither defaulted on its debt interest payments nor completely complied with the terms of London loans, and borrowing conditions were not similar to those encountered later. Summerhill recognizes the differences between these sub-periods. But a historian can conclude that the successful period of sovereign finance lasted about four decades and question whether that is a sufficient time span for assessing a financial revolution. Second, while Summerhill correctly identifies the enormous difference between the experience of Spanish- and Portuguese-American sovereign borrowing, the reader may wonder why, if Brazilians could identify and protect their financial interests while forming their first independent government, Spanish Americans could not also do so. Were the differences institutional or path dependent? A third overarching question is why, if decisions with respect to constraining sovereign borrowing protected private investors, the same category of decision makers would not bring a similarly constructive attitude to specifying the rules for constructing private financial markets? Summerhill implies that later in the century, legislators were committed to the economic structure of commercial export agriculture (especially the interests of coffee export.) That explanation fits with traditional interpretations of Brazilian economic history. However, it does not address why decision makers could incorporate new variables (investing in sovereign debt and financial credibility) in the first years after independence, but not do so in the second period under analysis, when the potential gains from financial and economic change were arguably greater.

None of these questions suggest that the book is wrong in its analyses; rather they provide the foundation for the large research agenda that Summerhill has opened. Inglorious Revolution is indispensible for all historians of Brazil and for all financial historians. The bibliography and footnotes alone justify the book. The addition of a 
deeply considered study of Brazilian finance is important for both historical and current studies of financial fragility. Taking up the questions that the book raises can also make important contributions to understanding long-term growth and inequality in locations where "development" did not happen or was delayed.

GAIL D. TRINER, Rutgers University

\section{GENERAL AND MISCELLANEOUS}

Education Matters. Global Schooling Gains from the $19^{\text {th }}$ to the $21^{\text {st }}$ Century. By Robert J. Barro and Jong-Wha Lee. New York: Oxford University Press, 2015. Pp. xi, 289. $\$ 34.95$, hardcover.

doi: $10.1017 / \mathrm{S} 0022050716000929$

Robert Barro and Jong-Wha Lee clearly believe that education matters if their scholarly collaboration over the past quarter-century is any indicator. Their 1993 article ("International Comparisons of Educational Attainment," The Journal of Monetary Economics 32, no .3 [1993]: 363-94) set forth the details of a data set they had compiled on adult educational attainment between 1960 and 1985 for 129 countries. This reflected their interest in cross country variation in educational attainment as a determinant of cross-country variation in rates of economic growth. Since then they have collaborated on extending the coverage of this data set both chronologically and geographically as well as making various modifications in estimation procedures in numerous publications. This data has become a standard source in cross country econometric analysis and ongoing updates are available at their website, barrolee.com. In the Preface to the book under review, the authors outline the further contributions to this effort they hope it will provide. These include providing estimates on school enrollment and educational attainment back to 1870 from a previous ending point in 1960, providing projections of educational attainment through 2040, developing a data set on the quality of education based on internationally comparable test scores, and utilizing both a 76 country panel data set spanning 1960 to 2010 and a 40 country panel data set with coverage at five year intervals between 1870 and 2010 to examine the effects of educational attainment on economic growth, fertility, and democracy.

The extent of the geographical and chronological coverage is impressive and this book is suggestive and informative in a number of respects. It provides a panorama of trends in educational attainment world-wide over the last century and a half. However, the book only reports trends by broad geographical areas; their country level estimates are available on their open access website. Their effort at projections of educational attainment over the next 30 years are quite suggestive pointing to the role of both changing age structure and recent increases in enrollment rates at various education levels on likely future trends in international educational attainment. The results in the two chapters on the effects of educational attainment are interpreted as supporting the authors' claims that education does indeed matter. One notable set of findings is that the impact of female educational attainment has a generally more positive impact on economic growth, negative impact on fertility and positive impact on prevalence of democracy compared with male educational attainment. One of these two chapters also 